BOVI, M.L.A.; RESENDE, M.D.V.; SPIERING, S.H. Genetic parameters estimation in King palm through a mixed mating system model. Horticultura Brasileira, Brasília, v. 21, n. 1, p. 93-98, março 2003.

\title{
Genetic parameters estimation in King palm through a mixed mating system model
}

\author{
Marilene L. A. Bovi ${ }^{1}$; Marcos Deon V. de Resende ${ }^{2}$; Sandra H. Spiering ${ }^{1}$ \\ ${ }^{1}$ IAC, C. Postal 28, 13.001-970 Campinas-SP, E-mail: mlabovi@cec.iac.br ${ }^{2}$ Embrapa Florestas, C. Postal 319, 83.411-000 Colombo- \\ PR, E-mail: deon@cnpf.embrapa.br
}

\begin{abstract}
Overestimation of the genetic parameters is common in palms due to the occurrence of geitonogamy and the absence of selfincompatibility mechanisms. Data from nursery grown Archontophoenix palms were utilized, assuming a mixed mating system including random cross-pollination and selfing at different rates. The objective was to show the importance of knowing the mating system predominant and define breeding strategies for that genus. Twenty-four King palm half sib families were evaluated at nursery conditions using a randomised complete block design, with nine replications and eleven plants per plot. Ten months after sowing, traits such as diameter, height, number of green leaves and length of the leaf sheath of the second leaf, were individually measured. Traits related to biomass were also estimated through regression procedure. It was concluded that King palm cannot be considered allogamous and the mixed mating system model should be used when estimating genetic parameters. At least $50 \%$ of selfing occurred at the time of pollination in the mother plants. The multi-effects index, using all random effects of the linear model, provided the highest selection accuracy for all traits, whatever the individual heritability level, and should be used in King palm heart-of-palm breeding programs. Under the allogamous model, the effective size of the studied population was equivalent to 93 unrelated individuals. This size was reduced to 32 palms under the mixed model; even so this population has enough variability to allow genetic progress by selection.
\end{abstract}

Keywords: Archontophoenix, Alexander palm, Bangalow palm, heritability, selection, growth traits.

\section{RESUMO}

Estimativa de parâmetros genéticos em palmeira real australiana por meio de modelo misto de reprodução

É comum a superestimativa de parâmetros genéticos em palmeiras devido à ocorrência de geitonogamia e a ausência de mecanismos que assegurem a autoincompatibilidade. Dados obtidos em viveiro com palmeiras do gênero Archontophoenix foram utilizados, assumindo um sistema reprodutivo misto, com a ocorrência ao acaso de diferentes taxas de polinização cruzada e autofecundação. O objetivo foi mostrar a importância do conhecimento do sistema reprodutivo predominante e definir estratégias de melhoramento para o gênero. Vinte e quatro famílias de meios-irmãos foram avaliadas em condições de viveiro usando o delineamento de blocos completos casualizados, com nove repetições e onze plantas por parcela. Dez meses após a semeadura, os seguintes caracteres foram individualmente mensurados: diâmetro, altura, número de folhas verdes e comprimento do limbo foliar da segunda folha. Caracteres relacionados à biomassa foram também estimados por meio de regressão. Concluiu-se que a palmeira real australiana não pode ser considerada como alógama e que o modelo que considera um sistema reprodutivo misto deve ser utilizado quando da estimativa de parâmetros genéticos para esse gênero. Estimou-se que pelo menos $50 \%$ de autofecundação ocorreu nas plantas matrizes. O índice multiefeitos, utilizando todos os efeitos ao acaso do modelo linear, proporcionou a maior acuracia de seleção para todos os caracteres avaliados, sendo recomendado seu uso em programas de melhoramento com Archontophoenix. Sob o modelo de alogamia o tamanho efetivo da população foi equivalente a 93 indivíduos não aparentados. Esse tamanho foi reduzido a 32 palmeiras quando o modelo misto foi considerado; mesmo assim há suficiente variabilidade para permitir progresso genético por seleção na população em estudo.

Palavras-chave: Archontophoenix, seafortia, herdabilidade, seleção, caracteres vegetativos.

(Recebido para publicação em 08 de fevereiro de 2002 e aceito em 26 de novembro de 2002)

L arge-scale palm plantations for heart-of-palm production have been done since 1990 utilizing fast growing species in replacement of predatory exploitation of Euterpe edulis Mart (Tabora et al., 1993; Bovi, 1997). Particular attention has been paid to fast growing palms that could provide a heart-of-palm similar to the one produced by the former. Two major Archontophoenix species, Australian palms utilized worldwide as ornamentals (Meerow, 1992; Jones,
1994; Lorenzi, 1996), have been recently cultivated in Brazil as a source of high quality heart-of-palm (Ramos $e t$ al., 1997; Bovi, 1998; Tagliari, 1998). Due to the increasing interest in this palm, a breeding program started with that genus including germplasm collection, seedling evaluation in nursery conditions and progeny tests in field trials.

Palms are perennial plants where breeding has been concerned primarily with yield characteristics of the individual. Emphasis is on general combining ability, which is most effectively handled by mass and family selection (Breure \& Bos, 1992; DurandGasselin et al., 1999). The length of generation time, added to space required for trials, limit the flexibility in the development of breeding populations (Hartley, 1977; Hardon, 1982). Another drawback is the mating system. Although palms are considered preferentially cross-pollinating species (Burquez et al., 1987; Tomlinson, 1990; 
Akpan, 1994; Bernal \& Ervik, 1996; Ervik \& Bernal, 1996), the selfing rating could be quite large due to the occurrence of geitonogamy and the absence of self-incompatibility mechanisms (Scariot et al., 1991; Bovi et al., 1994). Therefore, conventional genetic models cannot be applied to most palm species because they can result in overestimation of the genetic parameters. Cockerham and Weir (1984) proposed a model for species with a mixed reproductive system that allows better characterisation of the genetic structure of such populations.

The present paper deals with studies performed in nursery conditions with germplasm collected from cultivated populations of the Archontophoenix genus, taking into consideration traits highly related to heart-of-palm yield components (Clement \& Bovi, 2000; Bovi et al., 2001). The genetic variation and genetic gain associated with individual and multi-effect index selection (BLUP) in this breeding population were compared, assuming a mixed mating system including random cross pollination and selfing at different rates. This appears to be the first attempt to estimate genetic parameters and to improve King palm in the world.

\section{MATERIAL AND METHODS}

\section{Genetic material, statistical design and measurements}

The genetic material consisted of 24 open pollinated half-sib families obtained from Archontophoenix plants sampled in Santa Catarina, Brazil. The seeds were collected by researchers from EPAGRI and sent to Instituto Agronômico de Campinas in individually tagged plastic bags. The seeds were weighted and counted and set to germinate in polyethylene bags (14 cm open diameter x $20 \mathrm{~cm}$ height) in nursery conditions (75\% of sun incidence). The subtract was composed of soil and cow manure (3:1, in volume; with capacity for $1.26 \mathrm{~kg}$ or $1.3 \mathrm{~L}$ ) in accordance with the recommendation provided by Bovi (1998). Two months after sowing, the seedlings, in the one eophile stage, were set out in a randomised complete block design with 24 treatments, nine replications and eleven plants per single line plot.
The limes were everly spaced $(15 \mathrm{~cm}$ between bags) to avoid competition. Ten months after sowing, the plants were individually evaluated by measuring diameter, height, number of green leaves and length of the longest leaf (usually the second leaf), following standard practice used in palm research (Clement \& Bovi, 2000). As plant growth measurements represent the increase in plant material resulting from photosynthesis and mineral absorption, individual above-ground (shoot) and total biomass, at fresh (shofre and biofre) and dry weight basis (shodry and biodry), were estimated using destructive samples from a contiguous experiment, with plants from the same families, and a stepwise regression procedure. Another index of seedling growth utilized in this study was the product of leaf number and the length of the longest leaf (nulen). It has been shown that this non-destructive index increased exponentially with age in the same fashion as total seedling fresh weight (Corley, 1982).

\section{Statistical Model}

The linear model for an individual observation in the progeny test is:

$\mathrm{Y}_{\mathrm{ijk}}=\mathrm{u}+\mathrm{b}_{\mathrm{j}}+\mathrm{p}_{\mathrm{i}}+\mathrm{e}_{\mathrm{ij}}+\mathrm{d}_{\mathrm{ijk}}$, where: $\mathrm{u}$ $=$ general mean, fixed, $\mathrm{E}(\mathrm{u})=\mathrm{u}$ and $\mathrm{E}\left(\mathrm{u}^{2}\right)$ $=\mathrm{u}^{2}{ }_{{ }_{\mathrm{bj}}}=$ block effect, fixed, $\mathrm{E}\left(\mathrm{b}_{\mathrm{j}}\right)=0$ and $E\left(b_{j}^{2}\right)=0, p_{i}=$ progeny effect, random, $E\left(p_{i}\right)=0$ and $E\left(p^{2}\right)=b_{p}^{2} e_{i j}=$ plot effect $i j$, random, $E\left(e_{i j}\right)=0$ and $E\left(e^{2}\right)=\sigma_{e}^{2} ; d_{i j k}=$ Within plot effect ijk, random, $E\left(d_{i j k}\right)=0$ and $E\left(d_{i j k}^{2}\right)=\sigma_{d}^{2}$.

Genetic Parameters Estimation and Selection Methods

Genetic and phenotypic parameters estimates were obtained by using the SELEGEN, genetic statistical software, developed by Resende et al. (1994). Narrow sense heritability coefficients associated to individual within block $\left(\mathrm{h}^{2}\right)$, individual within plot, plot and family effects were estimated following expressions provided by Resende \& Higa (1994) and assuming a mixed mating system with self pollination rates varying from 0 to $70 \%$.

The optimal selection procedure (the one that maximizes the correlation between predictand and predictor) is given by the multi-effects index: $\mathrm{I}=\mathrm{b}_{1} \mathrm{~d}_{\mathrm{ijk}}$ $+b_{2} p_{i}+b_{3} e_{i j}$
The multi-effects index coefficients are:

$$
b_{1}=\frac{\left(1-\rho_{z}\right) \sigma_{\alpha}^{2}}{\sigma_{d}^{2}}=\text { 'heritability" }
$$

of the within plot effect;

$$
b_{2}=\frac{1+(n b-1) \rho_{\xi}}{\frac{n b}{\sigma_{z}^{2}+\sigma_{i s}^{2}+\sigma_{a}^{2} / n b}} \sigma_{a}^{2}=\quad,
$$

heritability" of the progeny effect;

$$
b_{3}=\frac{\left.\left(1-\rho_{g}\right) n\right] \sigma_{a}^{2}}{\sigma_{e}^{2}+\sigma_{d}^{2} / n}=\text { "heritability" }
$$

of the plot effect,

where $\mathrm{p}_{\mathrm{g}}$ is the additive genetic correlation between individuals within family: $\mathrm{p}_{\mathrm{g}}=(1 / 4)$ for half-sibs and $\mathrm{p}_{\mathrm{g}}=$ $(1 / 2)$ for full-sibs; $n$ is the number of plants per plot; $b$ is the number of replications and $\sigma_{\varepsilon}^{2}=\left(1 / \rho_{E}\right) \sigma_{z}^{2}$ is the additive genetic variance. For the balanced case, the multi-effects index is equivalent to individual (animal model) BLUP, as demonstrated by Resende \& Fernandes (1999).

The narrow sense heritability coefficients associated to individual within block $\left(\mathrm{h}^{2}\right)$, were estimated by the expression: $h^{2}=\frac{\sigma_{e}^{2}}{\sigma_{p}^{2}+\sigma_{e}^{2}+\sigma_{d}^{2}}$

\section{Genetic Model}

The genetic model reported by Cockerham \& Weir (1984) was used. Under this model the total genetic variance $\left(\sigma_{\mathrm{g}}^{2}\right)$ of a population with a mixed mating system is given by $\sigma_{z}^{2}=(1+F) \sigma_{a}^{2}+(1-F) \sigma_{2}^{2}+4 F D_{1}+F D_{2}$ $+F(1-F) H+\left(F_{e}-F^{2}\right)\left(H^{2}-H\right)$, where $\mathrm{F}$ is the Wright inbreeding coefficient (obtained from the selfing rate $S: F=S /(2-S))$ and $F_{c}$ is the joint inbreeding coefficient for two loci, given by $F_{c}=[F(1+2 F)] /(2+F)$. The following parameters are defined: $\left(\sigma_{\mathrm{a}}^{2}\right)$ : additive genetic variance; $\left(\sigma_{\mathrm{d}}^{2}\right)$ : dominance genetic variance; $D_{1}$ : covariance between additive effects and homozygous dominance effects; $D_{2}$ : genetic variance of the homozygous dominance effects; $\mathrm{H}$ : sum of the squared inbreeding depression effects; $\mathrm{H}^{2}$ : square of the sum of inbreeding 
Table 1. Individual narrow sense heritability coefficients associated to the different assumed selfing rates for nine variables from King palm families grown under nursery conditions at Campinas, Brazil. Campinas, IAC, 2000.

\begin{tabular}{lcccccccc}
\hline \multirow{2}{*}{ Trait } & \multicolumn{7}{c}{ Selfing rate (\%) } \\
\cline { 2 - 9 } & $\mathbf{0}$ & $\mathbf{1 0}$ & $\mathbf{2 0}$ & $\mathbf{3 0}$ & $\mathbf{4 0}$ & $\mathbf{5 0}$ & $\mathbf{6 0}$ & $\mathbf{7 0}$ \\
\hline Diameter & 1.41 & 1.08 & 0.83 & 0.64 & 0.49 & 0.37 & 0.26 & 0.18 \\
Height & 2.21 & 1.82 & 1.53 & 1.31 & 1.13 & 0.98 & 0.86 & 0.76 \\
Leaf length & 2.18 & 1.80 & 1.51 & 1.29 & 1.11 & 0.97 & 0.85 & 0.76 \\
Leaf number & 0.90 & 0.69 & 0.54 & 0.41 & 0.31 & 0.23 & 0.17 & 0.12 \\
Nulen & 3.92 & 3.01 & 2.32 & 1.79 & 1.36 & 1.02 & 0.74 & 0.50 \\
Shofre & 1.97 & 1.62 & 1.36 & 1.16 & 1.00 & 0.87 & 0.77 & 0.68 \\
Biofre & 2.30 & 1.91 & 1.60 & 1.37 & 1.18 & 1.03 & 0.90 & 0.80 \\
Shodry & 2.04 & 1.68 & 1.41 & 1.20 & 1.04 & 0.90 & 0.79 & 0.70 \\
Biodry & 1.97 & 1.62 & 1.37 & 1.16 & 1.00 & 0.87 & 0.77 & 0.68 \\
\hline
\end{tabular}

nulen - product of leaf number by the length of the longest leaf.

shofre and biofre - shoot and total biomass at fresh weight basis, respectively.

shodry and biodry - shoot and total biomass at dry weight basis, respectively.

depression effects. Using this model, Resende et al. (1995) derived the genetic relationship coefficients $\left(\mathrm{p}_{\mathrm{g}}\right)$, which permit the genetic parameters estimation and genetic gain prediction by taking into account the nature of the mixed mating system.

The multipliers associated to model with complete dominance are always equal or superior to those associated to the completely additive model. Then, taking the multipliers of the completely additive model is a conservative approach, which can lead, in the worst case, to underestimation of genetic gain. It can be pointed out that adopting the multipliers $4 /(1+S)^{2}, 2(1+S) /(1+$ $\mathrm{S})^{2} ; 1 ; 4(1+\mathrm{S})^{2}-1$ for the covariances associated to mass, parent, among families and within families is a safe strategy. Based on that, the present paper considered the completely additive model, using $(1+\mathrm{S})^{2} / 4$ as relationship coefficient $\left(\mathrm{p}_{\mathrm{g}}\right)$.

\section{Effective Population Size}

The effective population size $\left(\mathrm{N}_{\mathrm{e}}\right)$ of the breeding population was calculated by the following formulae (Resende, 2002):

$$
N_{e}=\frac{2(2-S) p n}{(1+S)^{2} \frac{\sigma_{n}^{2}}{n}+(1+S)^{2} n+\left(3-2 S-S^{2}\right)}
$$

Where $p$ is the number of families, $\mathrm{n}$ is the number of individuals per family; $S$ is the selfing rate and $\left(\sigma^{2}{ }_{n}\right)$ (which is zero in the present situation) is the variance of $n$. This expression is generic and can be used for allogamous species by setting $\mathrm{S}=0$, giving the formulae:

$$
N_{e}=\frac{4 p n}{\frac{\sigma_{v}^{2}}{n}+n+3}
$$

\section{RESULTS AND DISCUSSION}

Significant family differences were detected by the $\mathrm{F}$ test for all variables. This indicates that there is sufficient genetic variability to start a breeding program with this population aiming to improve growth traits closely linked to heart-of-palm yield (Clement \& Bovi, 2000; Bovi et al., 2001).

The experimental coefficients of variation (Cve\%) were low for all variables (ranging from 4.78 to 14.00), indicating high experimental precision and good assessment criteria. It can be concluded that directly measured traits could be evaluated with slightly low experimental error rates when compared to indirect ones. Higher variation coefficients have been generally reported in nursery conditions for other palms (Hartley, 1977; Satyabalan, 1984; Ramadasan et al., 1985).

The coefficient of genetic variation, expressed as percentage of the general mean, was low for leaf number (7.80), medium for plant diameter (16.08) and high for all the other variables (23.65 to $33.96)$, indicating greater genetic variation for those latter traits when compared to the former. It was noticed that the variable nulen had similar experimental precision and genetic variation as the total biomass at dry basis. Therefore, due to the easiness of being taken, it could be used as an index to evaluate King palm growth.

The individual narrow sense heritability coefficients associated with the different assumed selfing rates for the eight variables are presented in Table 1 . As expected by the low coefficient of variation and the high experimental precision, the heritability estimates showed high magnitudes. However, with only one exception (leaf number), all estimates for the zero selfing rate were out of the parameter space, i.e., higher than 1 . This shows that the genus can not be considered as an allogamous one and justifies the use of the mixed mating system model. Although, in the absence of reports on floral biology and the breeding system of this genus, in order to directly support our statement, morphological description (Tomlinson, 1990; Meerow, 1992; Dowe \& Hodel, 1994) coupled with field observations led us to conclude that Archontophoenix palms are monoecious, dichogamous and protandric. Single inflorescence units have male and female flowers disposed in triads (two males surrounding a central female flower) along raquilae segments. Male flowers dehiscent seems to occur frequently in 
Table 2. Estimates of the weights used in the multi-effects index (as defined in the material and methods), individual narrow sense heritabilty $\left(\mathrm{h}^{2}\right)$, accuracy of selection by the methods of individual (Ac-ind), family (Ac-f), within family (Ac-w) and multi-effects index selection (AcIME), as well as the relative efficiency of selection by the IME over the individual or mass selection (Efficiency) for nine variables from King palm families grown under nursery conditions at Campinas, Brazil. Campinas, IAC, 2000.

\begin{tabular}{lccccccccc}
\hline \multirow{2}{*}{ Trait } & \multicolumn{10}{c}{$\mathbf{9 0 \%}$ Selfing rate } \\
\cline { 2 - 10 } & $\mathbf{b}_{2}$ & $\mathbf{b}_{1}$ & $\mathbf{b}_{3}$ & $\mathbf{h}^{\mathbf{2}}$ & Ac-f & Ac-w & Ac-ind & Ac-IME & Efficiency \\
\hline Diameter & 0.94 & 0.37 & 0.10 & 0.49 & 0.71 & 0.38 & 0.69 & 0.81 & 1.17 \\
Height & 0.99 & 1.00 & 0.37 & 0.98 & 0.73 & 0.67 & 0.99 & 1.00 & 1.01 \\
Leaf length & 0.98 & 1.00 & 0.30 & 0.97 & 0.73 & 0.68 & 0.98 & 1.00 & 1.02 \\
Leaf number & 0.94 & 0.23 & 0.11 & 0.38 & 0.71 & 0.31 & 0.61 & 0.78 & 1.28 \\
Nulen & 0.98 & 1.00 & 0.25 & 0.90 & 0.73 & 0.64 & 0.93 & 0.97 & 1.04 \\
Shofre & 0.97 & 0.99 & 0.22 & 0.87 & 0.72 & 0.63 & 0.92 & 0.96 & 1.04 \\
Biofre & 0.98 & 1.00 & 0.33 & 1.00 & 0.73 & 0.74 & 1.00 & 1.00 & 1.00 \\
Shodry & 0.97 & 1.00 & 0.23 & 0.90 & 0.73 & 0.65 & 0.94 & 0.98 & 1.04 \\
Biodry & 0.98 & 0.96 & 0.24 & 0.87 & 0.73 & 0.62 & 0.92 & 0.96 & 1.04 \\
\hline
\end{tabular}

nulen - product of leaf number by the length of the longest leaf.

shofre and biofre - shoot and total biomass at fresh weight basis, respectively.

shodry and biodry - shoot and total biomass at dry weight basis, respectively.

the late afternoon or in the evening (Oldroyd et al., 1992). Although the sexual phases of one inflorescence unit are separated in time ( 8 to 28 days in a few observations carried out an cultivated specimens), there can be on overlap between different phases of one stem, since it is quite common to observe two to four inflorescences in the same palm at once. Therefore, selfing is possible and may be an essential feature of reproductive strategy of cultivated Archontophoenix. Also, there is no selfincompatibility mechanism on that genus, as indicated by the abundant fruit set of isolated vigorous cultivated palm. Entomophily (Cortopassi \& Ramalho, 1988; Oldroyd et al., 1992) and anemophily seem to be the effective pollination syndromes, although the importance of gravity, especially for the occurrence of geitonogamy, is also evident. The combination of these three pollination syndromes, favouring at the same time xenogamy and autogamy, clearly enhances the adaptability of the genus to a wide range of habitats. In fact, high adaptability is the major attribute of Archontophoenix palms, responsible for being utilized worldwide as ornamental (Meerow, 1992; Dowe \& Hodel, 1994; Jones, 1994). Archontophoenix seeds germinate fast and easily (Jones, 1994; Lorenzi, 1996; Bovi, 1998) and are mainly dispersed by birds (Innis, 1989) and mammals. The adaptability of Archontophoenix species is so high that recently Maunder et al. (2001) considered the species A. alexandrae as invasive. The authors reported that $A$. alexandrae is naturalised in low elevation valleys in Hawaii, having escaped from a botanic garden collection. Therefore, it appears that Archontophoenix species are in fact quite autogamous, because, in Brazil as well as in Hawaii, it has a high dispersion without great vigour lost, even coming from a restricted genetic base, as the founder stocks of botanical gardens, as pointed out by Maunder \& Culham (1998).

From the results of Table 1 , it can be pointed out that at least $50 \%$ of selfing occurred at the time of pollination in the mother plants that provided the studied population. This value of selfing rate made the estimates of heritability of almost all traits lower than 1 . Then, the genus is prone to be more autogamous than previously considered. The heritability measures the easiness of a trait, phenotypically evaluated in the parents, to be transmitted to the descendents (Falconer, 1981). Heritability estimates for vegetative traits in palm are hard to find. In oil palm some authors (Corley et al., 1973; Hardon et al., 1972; Breure
\& Corley, 1983) have shown that many of the growth and physiological parameters have medium to high heritabilities $(0.21$ to 0.65 for vegetative dry matter, for example) and are, therefore, more easily modified by selection. Ramadasan et al. (1985) observed that heritability was high (0.74) for shoot dry weight in coconut seedlings. Nishikawa (1995) reported heritability estimates based on progeny means for pejibaye (Bactris gasipaes Kunth) varying from 0.29 to 0.13 for plant diameter and from 0.61 to 0.35 for leaf number, at 6 and 14 months after planting, respectively. The same author found that heritability estimate for plant height was low (0.24). Clement (1995) reported heritability estimates for pejibaye higher than 1 for various traits. This author observed that in his studied population there were strong indications of inbreeding, with consequent overestimation of the additive genetic variance. It should be pointed out that any estimates of genetic variances and derived parameters are specific to the population sample in the studied environment. They varied also with crop development, i.e. plant ontogenetic stages (Falconer, 1981; Hodge \& White, 1992; Balocchi et al., 1993).

Assuming a selfing rate of $50 \%$, the estimates of narrow sense heritability 
associated with the random effects of the linear model, as well as the accuracy of selection by several methods and selection efficiency of the multi-effects index over mass selection, are presented in Table 2. It can be seen that multi-effects index (IME) provided the highest selection accuracy for all traits, whatever the individual heritability level. However, for the traits showing high heritability, mass selection led to similar accuracy. The relative efficiency of the multieffects index over mass selection, in terms of genetic gain, ranged from $1 \%$ to $28 \%$ (Table 1 ), except when $\mathrm{h}^{2}$ was one, in which case the superiority was zero. Then, the IME is recommended for use in heart-of-palm breeding programs. For the balanced case, this method is equivalent to the best linear unbiased prediction method or BLUP described by Henderson (1984).

Besides the overestimation of genetic parameters and gains, another feature of ignoring the mixed mating system of the genus is referring to overestimation of the effective population size of the breeding population. Under the allogamous model, the effective size of the present experimental population is equivalent to 93 unrelated individuals. Under the mixed model, the effective size is equivalent to only 32 unrelated individuals, which means a third part than previously thought. For the trait leaf number, the accuracy of selection by the IME under allogamy is 0.93 , reducing to 0.78 under the mixed mating system. This means an overestimation of $19 \%$ in genetic gain by ignoring selfing. The figure of 32 for the effective population size is still enough to provide genetic gain in the short and long-term recurrent selection programs. This is corroborated by the high levels of genetic variance as explicit by the genetic coefficients of variation, which ranged from $7.80 \%$ to $33.96 \%$ for the several traits.

To summarize, the mating system of the genus should be investigated by other studies, mainly using co-dominant genetic markers (isoenzymes, RFLP or microsatellites), as done recently for other plant species (Collevatti et al., 2001; Gaiotto et al., 2001). If confirmed, the predominance of selfing in such a palm will impact the breeding and germplasm collection strategies. With such selfing rate $(50 \%), 56.25 \%$ of the genetic variability is among families and only $43.75 \%$ is within family (this is given by $(1+\mathrm{S})^{2 / 4}$ and $1-(1+\mathrm{S})^{2 / 4}$, respectively). These values are contrasting to $25 \%$ and $75 \%$ under allogamy. Therefore, the germplasm collection should emphasize a great number of mother trees (or populations) with a few individuals per each. In its turn, the breeding strategies should rely on among families' evaluation and selection.

\section{ACKNOWLEDGEMENTS}

The authors expressed their gratitude to Teresinha Catarina Heck Schallemberger, from EPAGRI, for the genetical material.

\section{CITED LITERATURE}

AKPAN, E.E.J. Evaluation of tall coconut (Cocos nucifera L.) genotypes within the Nigerian coconut germplasm bank. Oleagineux, v. 49, n. 1, p. 13-20, 1994.

BALOCCHI, C.E.; BRIDGEWATER, F.E.; ZOBEL, B.J.; JAHROMI, S. Age trends in genetic parameters for tree height in a nonselected population of loblolly pine. Forest Science, v. 39, n. 2, p. 231-251, 1993.

BERNAL, R.; ERVIK, F. Floral biology and pollination of the dioecious palm Phytelephas seemannii in Colombia: an adaptation to staphylinid beetles. Biotropica, v. 28, n. 4, p. $682-$ 696, 1996.

BOVI, M.L.A. Expansão do cultivo da pupunheira para palmito no Brasil. Horticultura Brasileira, Brasília, v. 15, Suplemento, p. 183-185, 1997.

BOVI, M.L.A. Cultivo da palmeira real australiana visando à produção de palmito. Campinas: Instituto Agronômico, 1998. 26 p. (Boletim Técnico 172). BOVI, M.L.A.; VAL, M.R.; DIAS, G.S.; SPIERING, S.H. Floral biology and reproductive system of Euterpe espiritosantensis Fernandes. Acta Horticulturae, v. 360, n. 1, p. 41-56, 1994. BOVI, M.L.A.; SAES, L.A.; UZZO, R.P.; SPIERING, S.H. Adequate timing for heart-ofpalm harvesting in King palm. Horticultura Brasileira, Brasília, v. 19, n. 2, p. 135-139, 2001.

BREURE, C.J.; BOS, J. Development of elite families in oil palm (Elaeis guineensis Jacq.). Euphytica, v. 64, n. 1-2, p. 99-112, 1992.

BREURE, C.J.; CORLEY, R.H.V. Selection of oil palm for high density planting. Euphytica, v. 32, p. 177-186, 1983.

BURQUEZ, A.; SARUKHAN, K.J.; PEDROZA, A.L. Floral biology of a primary rain forest palm, Astrocaryum mexicanum Libm. Botanical Journal of the Linnean Society, v. 94, n. 1, p. 407-419, 1987.
CLEMENT, C.R. Growth and genetic analysis of pejibaye (Bactris gasipaes Kunth, Palmae) in Hawaii. Honolulu: University of Hawaii, 1995. 221 p. (Tese doutorado).

CLEMENT, C.R.; BOVI, M.L.A. Padronização de medidas de crescimento e produção em experimentos com pupunheira para palmito. Acta Amazonica, Manaus, v. 30, n. 3, p. 349-362, 2000. COCKERHAM, C.C.; WEIR, B.S. Covariances of relatives stemming from a population undergoing mixed self and random mating. Biometrics, v. 40, n. 1, p. 157-164, 1984.

COLlEVATTI, R.G.; GRATTAPAGLIA, D.; HAY, J.D. High resolution microsatellite based analysis of the mating system allows the detection of significant biparental inbreeding in Caryocar brasiliense, an endangered tropical tree species. Heredity, v. 86, n. 1, p. 60-67, 2001.

CORLEY, R.H.V. Germination and seedling growth. In: CORLEY, R.H.V.; HARDON, J.J.; WOOD, B.J. (eds.) Oil palm research. Amsterdam: Elsevier Scientific Publishing Company, 1982. p. 23-36.

CORLEY, R.H.V.; HARDON, J.J.; OOI, S.C. Some evidence for genetically controlled variation in photosynthetic rate of oil palm seedlings. Euphytica, v. 22, n. 1, p. 48-55, 1973.

CORTOPASSI, L.M.; RAMALHO, M. Pollen harvest by africanized Apis mellifera and Trigona spinipes in São Paulo. Botanical and ecological views. Apidologie, v. 19, n. 1, p. 1-23, 1988.

DOWE, J.L.; HODEL, D.R. A revision of Archontophoenix H. Wendl. \& Drude (Arecaceae). Austrobaileya, v. 4, n. 2, p. 227-244, 1994.

DURAND-GASSELIN, T.; BAUDOUIN, L.; COCHARD, B.; ADON, B.; CAO, T.V. Oil palm genetic improvement strategies. Plantations, Recherche, Developpment, v. 6, n. 5, p. 344-358, 1999. ERVIK, F.; BERNAL, R. Floral biology and insect visitation of the monoecious palm Prestoea decurrens on the Pacific Coast of Colombia. Principes, v. 40, n. 2, p. 86-92, 1996.

FALCONER, D.S. Introduction to quantitative genetics. 2. ed. London: Longman, 1981. 365 p. GAIOTTO, F.A.; BRONDANI, R.P.V.; GRATTAPAGLIA, D. Microsatellite markers for heart of palm, Euterpe edulis and E. oleracea. Molecular Ecology Notes, v. 1/2, n. 1, p. 86-88, 2001.

HARDON, J.J. Oil palm breeding - Introduction. In: CORLEY, R.H.V.; HARDON, J.J.; WOOD, B.J. (eds.) Oil Palm Research. New York: Elsevier, 1982. p. 89-108.

HARDON, J.J.; OOI, S.C.; CORLEY, R.H.V. Analysis of growth in oil palm.2. Estimation of genetic variances of growth parameters and yield of fruit bunches. Euphytica, v. 21, n. 2, p. 252264, 1972.

HARTLEY, C.W.S. The oil palm (Elaeis guineensis Jacq.), 2 ed. London: Longman, Tropical Agriculture Series. 1977. 806 p.

JONES, D.L. Palms throughout the world. Washington: The Smithsonian Institution Press, 1994. 410 p. HENDERSON, C.R. Aplications of linear models in animal breeding. Guelph: University of Guelph, 1984. $462 \mathrm{p}$.

HODGE, G.R.; WHITE, T.L. Genetic parameter estimates for growth traits at different ages in slash pine and some implications for breeding. Silvae Genetica, v. 41, n. 4-5, p. 252-262, 1992. 
INNIS, G.J. Feeding ecology of fruit pigeons in subtropical rainforests of southeastern Queensland. Australian Wildlife Research, v. 16, n. 4, p. 365-394, 1989.

LORENZI, H. Palmeiras no Brasil: exóticas e nativas. Nova Odessa: Editora Plantarum, 1996. $303 \mathrm{p}$.

MAUNDER, M.; CULHAM, A. The role of botanic gardens in supporting plan reintroductions. Dodonea, v. 65, p. 81-90, 1998. MAUNDER, M.; LYTE, B.; DRANSFILED, J.; BAKER, W. The conservation value of botanic garden palm collections. Biological Conservation, v. 98, p. 259-271, 2001.

MEEROW, A.W. Betrock's guide to landscape palms. Cooper City: Betrock Information System, Inc., 1992. $153 \mathrm{p}$.

NISHIKAWA, M.A.N. Seleção entre e dentro de progênies de meios irmãos de pupunha (Bactris gasipaes H.B.K.). Jaboticabal: UNESP, 1995. 89 p. (Tese mestrado)

OLDROYD, B.; RINDERER, T.; WONGSIRI, S

Pollen resource partitioning by Apis dorsata, A. cerana, A. andreniformis and A. florea in Thailand. Journal of Apicultural Research, v. 31, n. 1, p. 37, 1992.
RAMADASAN, A.; KASTURI-BAI, K.V.; SHIVASHANKAR, S.; VIJAYAKUMAR, $\mathrm{K}$ Heritability of seedling vigour in coconut palm. Journal of Plantation Crops, v. 13, n. 2, p. 136138, 1985.

RAMOS, M.G.; SCHALLEMBERGER, T.C.H.; MOLINARI, A.J. Normas técnicas do cultivo da palmeira-real-da-austrália para produção de palmito. Santa Catarina: EPAGRI, 1997. 16 p. (Sistemas de Produção 26).

RESENDE, M.D.V. Genética biométrica e estatística no melhoramento de plantas perenes. Brasília: Embrapa Informação Tecnológica, 2002. 975 p. RESENDE, M.D.V.; OLIVEIRA, E.B.; MELINSKI, L.C.; GOULART, F.S.; OAIDA, G.R SELEGEN - Seleção Genética Computadorizada: manual do usuário. Colombo: EMBRAPA-CNPF, 1994, $31 \mathrm{p}$.

RESENDE, M.D.V.; HIGA, A.R. Maximização da eficiência da seleção em testes de progênies de Eucalyptus através da utilização de todos os efeitos do modelo matemático. Boletim de Pesquisa Florestal, Colombo, v. 28/29, p. 37-55, 1994.

RESENDE, M.D.V.; FERNANDES, J.S.C. Procedimento BLUP individual para delineamentos experimentais aplicados ao melhoramento florestal. Revista de Matemática e Estatística, São Paulo, v. 17, n. 1, p. 89-107, 1999.
RESENDE，M.D.V.; VENCOVSKY, R.; FERNANDES, J.S.C. Selection and genetic gains in populations of Eucalyptus with a mixed mating system. In: IUFRO CONFERENCE, 1995, Hobart. Proceedings... Hobart: IUFRO, 1995. p. 191-193.

SATYABALAN, K. Genetic improvement of coconut palm. Indian Coconut Journal, v. 15, n. 3-4, p. 3-11, 1984.

SCARIOT, A.O.; LLERAS, E.; HAY, J.D. Reproductive biology of the palm Acrocomia aculeata in central Brazil. Biotropica, v. 23, n. 1, p. 12-22, 1991.

TABORA, P.C.JR.; BALICK, M.J.; BOVI, M.L.A.; GUERRA, M.P. Hearts of Palm (Bactris, Euterpe and others). In: J.P. WILLIAMS (ed.). Pulses and Vegetables. London: Chapman and Hall, 1993. p. 193-218.

TAGLIARI, P.S. Palmeira real impulsiona produção de palmito em Santa Catarina. Agropecuária catarinense, Florianópolis, v. 11, n. 3, p. 61-65, 1998.

TOMLINSON, P.B. The structural biology of palms. London: Claredon Press, Oxford, 1990. 463 p. 